Research Paper

\title{
Properties of Lewis Lung Carcinoma Cells Surviving Curcumin Toxicity
}

\author{
Dejun Yan', Michael E. Geusz'1, and Roudabeh J. Jamasbi1,2凶
}

1. Department of Biological Sciences, Bowling Green State University, Bowling Green, $\mathrm{OH} 43403$, USA

2. Department of Public and Allied Health, Bowling Green State University, Bowling Green, OH 43403, USA

$\triangle$ Corresponding author: Roudabeh Jamasbi, PhD, Department of Public and Allied Health, Department of Biological Sciences, 204 Life Sciences Building, Bowling Green State University, Bowling Green, OH 43403. (419) 372-8724; Fax: 419-372-2024; Email: rjamasb@bgsu.edu

(C) Ivyspring International Publisher. This is an open-access article distributed under the terms of the Creative Commons License (http://creativecommons.org/ licenses/by-nc-nd/3.0/). Reproduction is permitted for personal, noncommercial use, provided that the article is in whole, unmodified, and properly cited.

Received: 2011.10.18; Accepted: 2011.12.15; Published: 2011.12.22

\begin{abstract}
The anti-inflammatory agent curcumin can selectively eliminate malignant rather than normal cells. The present study examined the effects of curcumin on the Lewis lung carcinoma (LLC) cell line and characterized a subpopulation surviving curcumin treatments. Cell density was measured after curcumin was applied at concentrations between 10 and $60 \mu \mathrm{M}$ for 30 hours. Because of the high cell loss at $60 \mu \mathrm{M}$, this dose was chosen to select for surviving cells that were then used to establish a new cell line. The resulting line had approximately $20 \%$ slower growth than the original LLC cell line and based on ELISA contained less of two markers, NF-KB and ALDHIA, used to identify more aggressive cancer cells. We also injected cells from the original and surviving lines subcutaneously into syngeneic C57BL/6 mice and monitored tumor development over three weeks and found that the curcumin surviving-line remained tumorigenic. Because curcumin has been reported to kill cancer cells more effectively when administered with light, we examined this as a possible way of enhancing the efficacy of curcumin against LLC cells. When LLC cells were exposed to curcumin and light from a fluorescent lamp source, cell loss caused by $20 \mu \mathrm{M}$ curcumin was enhanced by about $50 \%$, supporting a therapeutic use of curcumin in combination with white light. This study is the first to characterize a curcumin-surviving subpopulation among lung cancer cells. It shows that curcumin at a high concentration either selects for an intrinsically less aggressive cell subpopulation or generates these cells. The findings further support a role for curcumin as an adjunct to traditional chemical or radiation therapy of lung and other cancers.
\end{abstract}

Key words: Lewis lung carcinoma, curcumin, cancer stem cell, phototoxicity.

\section{Introduction}

Curcumin, a yellow-orange dye in the spice turmeric, causes selective apoptosis in many cancer cell types including those of small-cell lung cancer while sparing normal cells (1-4). The therapeutic effects of curcumin against carcinogensis and progression of tumor growth depend on its inhibition of multiple intracellular signaling molecules, most notably NF- $\mathrm{KB}$ that plays a central role in various responses leading to host defense and also inflammation (5-7). Curcumin has been documented in the Indian medical system Ayurveda for over 6000 years and is still prominent in the diets of Asian countries (8). Although orally administered curcumin is re- markably well tolerated and has been evaluated as a supplemental chemotherapeutic drug, its bioavailability is very poor. Oral administration of curcumin has shown no effect on mammary, liver, kidney (9) or lung cancers (10). Improvements in bioavailability are needed to increase the effectiveness of this promising drug, particularly for targets outside the gastrointestinal tract. Alternative therapeutic approaches are to administer curcumin either directly to tumors or through the circulatory system either alone or in combination with more traditional cancer treatments. When administered with radiation (11-16) or chemotherapy (17-20) curcumin sensitizes the tumor to the 
treatment and improves outcome $(21,22)$.

Many cancers return following chemotherapy because of resistant cells. In some cases, resistance has been attributed to cancer stem cells (CSCs), a small subpopulation of self-renewing cells that are thought to be critical for tumor recurrence and progression and that can proliferate after chemotherapy and radiation therapy $(23,24)$. In light of the potential benefits of curcumin delivered in combination with standard cancer therapies, it will be important to characterize cells showing tolerance to curcumin. A few reports have identified the properties of curcumin-surviving subpopulations of tumors or cancer cell lines (25-28). Any examination of curcumin-resistance should consider the possible presence of CSCs.

In this study, we investigated the effect of curcumin on the Lewis lung carcinoma (LLC) cell line. The LLC line is a well-established mouse cancer model that is commonly used as a transplantable malignancy model in syngeneic C57BL/6 mice. We also generated and characterized a curcumin-surviving LLC sub-population and tested its ability to form tumors in mice. Finally, we used LLC cells to replicate a reported synergistic effect of light and curcumin on cancer cells as a possible way of increasing the efficacy of curcumin.

\section{Materials and Methods Animals}

A transgenic mPer1::luc mouse line that we used previously to produce LLC tumors (29) was bred and maintained in the BGSU Animal Care Facility under standard conditions of $12 \mathrm{hr}$ light:12 hr dark and fed a reduced-fat mouse chow ad libitum. The mice were originally produced by Dr. Hajime Tei of Mitsubishi Kagaku Institute of Life Sciences, Tokyo through oocyte injection and were on a C57BL/ 6 background (30). Although not utilized in this study, these mice contain the firefly luciferase gene luc controlled by the promoter of the mPer1 gene, enabling bioluminescence imaging of tumor growth (29). The mice received humane care in accordance with the BGSU Institutional Animal Care and Use Committee (IACUC).

\section{Lewis Lung Carcinoma (LLC) cell line}

The LLC cell line was provided by Dr. Stephen Kennel of the University of Tennessee Medical Center, Knoxville, TN. The cells were cultured in Dulbecco's modified eagle medium (DMEM, GIBCO, Invitrogen, NY), supplemented with penicillin $(100 \mathrm{U} / \mathrm{ml})$, streptomycin $(100 \mu \mathrm{g} / \mathrm{ml})$ and 5 or $10 \%$ fetal bovine serum (FBS, Atlanta Biological, Lawrenceville, GA), referred to here as complete DMEM. The cultured cells were kept in 100-mm tissue culture dishes at $37^{\circ} \mathrm{C}$ in a humidified atmosphere containing $5 \% \mathrm{CO}_{2}$ (31).

\section{Curcumin treatment}

To determine the dose-dependent effect of curcumin on LLC cells, the cultured cells were washed, trypsinized, collected, counted using a hemocytometer (Hausser Scientific, PA) and subsequently plated in 24-well plates at a density of $5 \times 10^{4}$ cells/well and incubated at $37^{\circ} \mathrm{C}$. Curcumin (purity $70 \%$, Sigma) was dissolved in DMSO, and diluted in complete DMEM to provide a curcumin concentration ranging from 10 to $60 \mu \mathrm{M}$. Twenty-four hours after plating, each of the four-well columns was washed with PBS once, and each column was exposed to $10,20,40$ or $60 \mu \mathrm{M}$ curcumin. Four wells treated with complete DMEM or complete DMEM with $0.2 \%$ DMSO served as controls. After incubation, the cell density was assayed with the crystal violet staining method according to a standard protocol (32). The resulting absorbance of the stained cells was analyzed with ANOVA (OriginLab, Northampton, MA). The experiment was repeated with $2,4,8,16,24$, or $30 \mathrm{hrs}$ of curcumin exposure using a range of curcumin dosages.

\section{Curcumin-surviving LLC sub-population}

To select for a curcumin-surviving cell subpopulation, LLC cells were plated into three $100-\mathrm{mm}$ cell culture plates ( $10^{6}$ cells/plate) containing $10 \mathrm{ml}$ complete DMEM and incubated at $37^{\circ} \mathrm{C}$. After 24 hours, the medium was removed and the cells were incubated in complete DMEM containing $60 \mu \mathrm{M}$ curcumin dissolved in $0.2 \%$ DMSO for $30 \mathrm{hrs}$. After incubation, the curcumin-containing medium was removed and replaced with complete DMEM to allow cells that survived the treatment to grow. After the surviving cells formed colonies (normally four weeks after treatment), they were passaged three times. The cell line that developed was designated the curcumin-surviving LLC line.

\section{Growth Curve}

To determine the rate of growth of both cell lines, cultured cells were trypsinized, collected, counted and plated in 100-mm culture plates at a density of $10^{6}$ cells/plate. The cells were trypsinized, collected, and counted at 16, 24, 48, 72 and 96 hours after plating. For statistical analysis, three plates of cells were used at each time point.

\section{Enzyme-Linked Immunosorbent Assay (ELISA)}

ELISA was performed as described previously 
(31). Briefly, the original LLC line and the curcumin-surviving line were washed with PBS, trypsinized, collected, counted, and plated into 96-well plates $\left(5 \times 10^{4}\right.$ cells/well). After incubation at $37^{\circ} \mathrm{C}$ for $24 \mathrm{hrs}$, the plates were washed with PBS once and the cells were fixed with methanol for 10 minutes. The plates were then washed with PBS twice and incubated with $100 \mu$ l complete DMEM containing rabbit polyclonal antibodies (anti-p65, Santa Cruz Biotechnology, SC-109, $200 \mu \mathrm{g} / \mathrm{ml}$ and anti-ALDH1A1, Proteintech Group, $15910-1-\mathrm{AP}, 133 \mu \mathrm{g} / \mathrm{ml}$ ) at $37^{\circ} \mathrm{C}$ for two hours. The antibodies were tested at a range of dilutions (1:50, 1:100, 1:200, 1:400). Three replicates of each dilution were used for statistical analysis. One well with only cells was used as blank for each plate. After two hours of incubation at $37^{\circ} \mathrm{C}$, the wells were washed three times with PBS to remove any unbound primary antibody and incubated with $100 \mu \mathrm{ll}$ $\beta$-galactosidase-conjugated goat anti-rabbit secondary antibody (1:500 dilution in complete DMEM) at $37^{\circ} \mathrm{C}$ for another two hrs. After incubation, the wells were washed with PBS three times and the cells were incubated with $100 \mu \mathrm{l}$ substrate solution $(1 \mathrm{mg} / \mathrm{ml}$ P-nitrophenyl $\beta$-D-galactopyranoside in phosphate buffer, $\mathrm{pH}$ 8.0) at $37^{\circ} \mathrm{C}$ for one hour in darkness. The development of a yellow color indicated a positive reaction. The intensity of the color was measured with a MR-600 microwell plate reader (Dynatech Lab. Inc.) at $410 \mathrm{~nm}$ wavelength. The resulting absorbance was analyzed using ANOVA.

\section{Tumor injection and histology}

The upper rear leg of the mice was injected subcutaneously with $10^{6}$ LLC cells diluted in PBS. Three weeks after the injection, tumors were excised from euthanized mice, fixed in Histochoice (Amresco, Solon, $\mathrm{OH})$ and embedded in paraffin at $57^{\circ} \mathrm{C}$. Sections (5 to $10-\mu \mathrm{m}$ thick) were mounted on glass slides, dewaxed, rehydrated through a series of ethanol dilutions and stained with hematoxylin and eosin for histological analysis.

\section{Curcumin and light treatment}

To investigate the effect of curcumin in combination with visible light, we plated the LLC cells in 24 -well plates at a density of $5 \times 10^{4}$ cells/well. After 24 hours of incubation at $37^{\circ} \mathrm{C}$, the cells were exposed to $10,20,40$ or $60 \mu \mathrm{M}$ curcumin. After one-hour incubation, the cells were irradiated for 5 minutes with fluorescent light with an intensity of $120 \mu$ Einsteins $\mathrm{m}^{-2}$ $\mathrm{s}^{-1}$ (measured with Apogee Instrument's Quantum Meter). The light source was a portable fluorescent light table containing one 13-watt tube directing light upwards through a white plastic diffuser, which was placed below two cool white F20T12 fluorescent bulbs (1200 lumens, Eco Lux Technology) positioned $90 \mathrm{~mm}$ above the light table. Each cell culture plate was placed at the center of the light table and irradiated simultaneously from above and below. While the experimental plates were exposed to light, the control plates (treated with curcumin but not exposed to light) were removed from the incubator and kept in darkness under the same conditions as the experimental group (at room temperature and in room air). After the light treatment, all the plates were returned to the $37^{\circ} \mathrm{C}$ incubator and remained in the curcumin medium for a total of 24 hours exposure. The cells were then stained with crystal violet and the cell density was analyzed as described above.

\section{Results}

\section{The Effect of Curcumin on LLC Cells}

The dose-dependent effect of curcumin on LLC cells over a range of exposure times is shown in Figure 1A. The 2-hr curcumin exposure had a significant effect only at $60 \mu \mathrm{M}$, whereas the $8-\mathrm{hr}$ and $16-\mathrm{hr}$ treatments were able to cause significant reduction of cells given the lower concentrations. The effect of 24-hr exposure was significant at 20-60 $\mu \mathrm{M}$, and was similar to that at 30-hr exposure. The cell density of the curcumin-free control plate almost doubled during the 30-hr period, while the higher curcumin dosages caused a decline (Fig. 1A). Cells treated with DMSO were not significantly different from cells given complete medium alone. Cell viability after treating LLC cells with 5, 10, 20, and $40 \mu \mathrm{M}$ curcumin for $24 \mathrm{hrs}$ was also evaluated using the MTT assay (data not shown). A significant $50 \%$ reduction in cell staining occurred between 20 and $40 \mu \mathrm{M}$ (ANOVA, $\mathrm{F}=5.646, \mathrm{p}=0.00129$ ).

\section{Comparing the Curcumin-Surviving and Original LLC Cell Lines}

According to the dose-response curves, we chose a 30-hr exposure with $60 \mu \mathrm{M}$ curcumin to select a curcumin-surviving sub-population. To assess the difference between the curcumin-surviving and original LLC lines, we compared growth rate and responses to curcumin along with expression of NF-kB and ALDH1A1, both of which are markers associated with aggressive cancer cells such as CSCs. We treated the LLC line and the curcumin-surviving line with the same curcumin concentrations to establish a second set of dose-response curves (Fig. 1B). The curcumin-surviving line was slightly less sensitive to curcumin than the original line. 

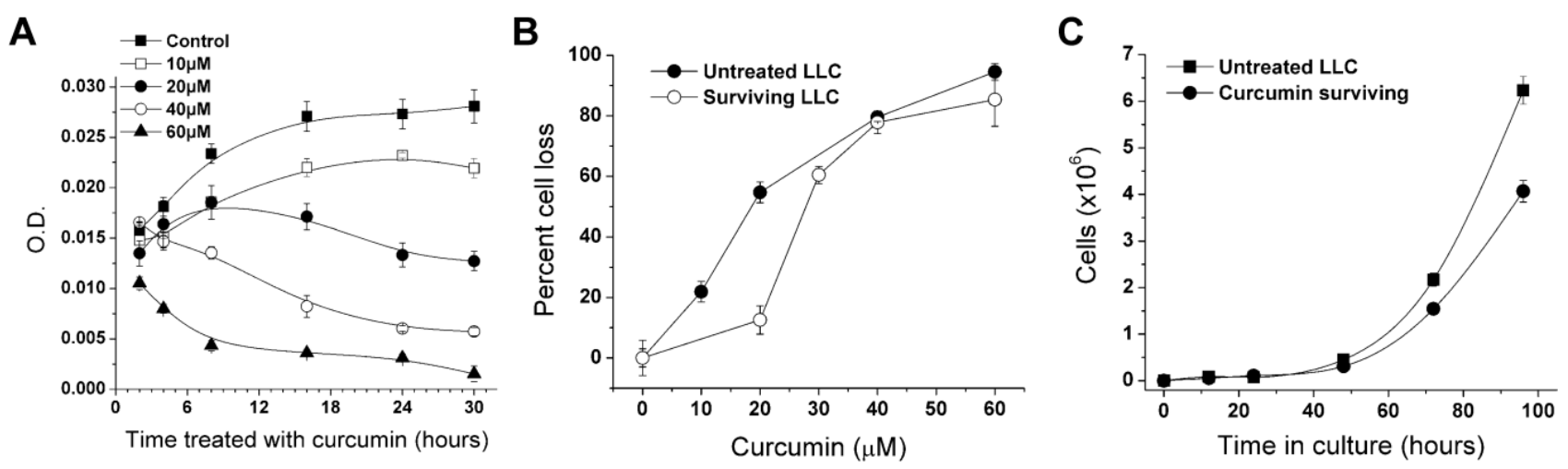

Figure I. Reduction of LLC cell proliferation in response to curcumin exposure. A. Shown is the loss of cells caused by varying the curcumin $(0-60 \mu \mathrm{M})$ and treatment interval $(2-30 \mathrm{hrs})$. Each line represents the effect of one dosage of curcumin and each point is the mean absorbance in a crystal violet assay from four wells \pm SD. B. Reduction of curcumin-surviving LLC cells in response to a second exposure of curcumin $(0-60 \mu \mathrm{M}$ for $30 \mathrm{hrs})$ compared with the original LLC cell line treated for $30 \mathrm{hrs}$. Percent cell loss is the percent decline in absorbance relative to the DMSO control. Each point is mean absorbance of four wells \pm SD. C. The growth rate of curcumin-surviving and original LLC lines. Cell counts were made at 16, 24, 48, 72 and $96 \mathrm{hrs}$ after plating. Each point is the mean of the number of cells in three plates \pm SD.

Growth rate measurements showed that the curcumin-surviving line had an approximately $20 \%$ slower growth rate than the untreated LLC line (Fig. 1C). After $96 \mathrm{hrs}$ of culture, the original LLC line had approximately $50 \%$ more cells than the curcumin-surviving line (Fig. 1C). ELISA was performed on both lines to determine the expression of NF-KB and ALDH1A1. The curcumin-surviving line showed a lower amount of ALDH1A1 and NF-KB than the original line (Table $1, \mathrm{~T}$-test, $\mathrm{p}<0.05$, using 1:100 antibody dilution).

Table I. Evaluation of cancer stem cell markers by ELISA

\begin{tabular}{|c|c|c|c|c|}
\hline \multirow{2}{*}{$\begin{array}{l}\text { Primary } \\
\text { Antibody } \\
\text { Dilution }\end{array}$} & \multicolumn{2}{|l|}{ NF-кB level } & \multicolumn{2}{|c|}{ ALDH1A1 level } \\
\hline & $\begin{array}{l}\text { Original } \\
\text { LLC line }\end{array}$ & $\begin{array}{l}\text { Curcumin } \\
\text { treated LLC } \\
\text { line }\end{array}$ & $\begin{array}{l}\text { Original } \\
\text { LLC line }\end{array}$ & $\begin{array}{l}\text { Curcumin } \\
\text { treated LLC } \\
\text { line }\end{array}$ \\
\hline $1: 100$ & $1.233 \pm 0.10$ & $1.000 \pm 0.10$ & $0.354 \pm 0.006$ & $0.108 \pm 0.001$ \\
\hline $1: 200$ & $0.664 \pm 0.05$ & $0.383 \pm 0.04$ & $0.123 \pm 0.04$ & $0.056 \pm 0.10$ \\
\hline 1:400 & $0.294 \pm 0.08$ & $0.066 \pm 0.01$ & $0.0985 \pm 0.02$ & $0.047 \pm 0.02$ \\
\hline
\end{tabular}

Shown is the average optical density of three wells at $410 \mathrm{~nm} \pm$ SD.

\section{Comparison of Curcumin-Surviving Line and the Original LLC Cell Line in vivo}

Mice that were of the same genetic background as the LLC cells were used to compare the tumorigenicity of the original LLC line and the curcumin-treated cell line. Three mice were injected in the upper right leg with $10^{6}$ cells from the curcu- min-surviving line at the third passage after treating LLC cells with curcumin. Three weeks later, each mouse had developed small tumors that were then removed by dissection. There was no evidence of metastasis in lung, spleen, liver, intestine, heart or other tissues examined. Histological sections made from the tumors revealed cell types found previously in tumors made from the original line (29). For example, a compact central area of cancer cells and infiltrating stromal cells, as described previously, were also present in tumors from the surviving-cell line (Fig. 2). The only obvious difference was that tumors of the surviving cell line appeared to contain more closely spaced blood vessels passing through the mass of cancer cells (Figure 2A).

In a second experiment, three mice were injected with the surviving line and three were injected with the original line. Tumors formed in all mice of both groups and, as in the first experiment, there was no evidence of metastasis at the macroscopic level. Furthermore, the tumors from the curcumin-surviving line appeared to be more heavily vascularized than tumors from the original line (Figure 2C).

\section{The Effect of Curcumin and Light on LLC cells}

It has been shown that curcumin in combination with light inhibits the growth of E. coli (33), transformed skin keratinocytes (34) and A-431 tumors in a xenograft mouse model (35), thereby providing a possible way to increase the effectiveness of curcumin by combining it with photodynamic therapy of tumors. We tested whether this effect can also be detected with the LLC cell line. We evaluated whether 
possible phototoxicity or light-absorption by the phenol red of normal cell culture media influences the combined curcumin-light effect. LCC cells were maintained in phenol red containing medium (complete DMEM) and non-phenol red complete medium. Above $10 \mu \mathrm{M}$ the curcumin treatments in combination with light produced a greater cell loss than curcumin alone in cells maintained in complete DMEM (Fig. $3 \mathrm{~A})$. Above this same dosage cucumin also reduced the LLC cell cultures maintained in phenol red-free medium more effectively when combined with light exposure (Fig. 3B).

Light itself also produced a loss of cells when delivered without curcumin to LLC cells in either medium. This effect was larger in the phenol red-free medium $(39.23 \%)$ than in complete DMEM (19.78\%), as shown in Fig. 3A, B. When these results were plotted as the percentage of the absorbance in the curcumin-free group (Fig. 3C, D), treatments above $10 \mu \mathrm{M}$ produced a substantial effect in the complete medium and only a modest effect in the phenol red-free medium.

Figure 2. Sections through tumors formed from the curcumin-surviving LLC cell line. A. Shown are LLC cells, with blue nuclei, near the boundary of the tumor where it is infiltrated with blood cells (small arrow) and numerous blood vessels (large arrow). B. Sections also showed infiltration of muscle cells into the tumor (arrow). C. A representative section from a tumor made from the original LLC cell line. The sections were stained with hematoxylin and eosin, and the scale bar equals $50 \mu \mathrm{m}$.

\section{Discussion}

Among all cancers, lung cancer is considered one of the deadliest because of aggressive tumor cell growth and lack of adequate therapies. We selected a well studied lung cancer cell line to evaluate the use of curcumin at concentrations that are known to be cytotoxic to many different cancer cells (36). Previously, when LLC cells were used in an orthotopic tumor model, with the cells implanted in the lungs, curcumin administered orally had no effect on tumor growth but did minimize metastasis to lymph nodes near the lungs (37), suggesting that curcumin or its metabolites had some effects despite low bioavailability following ingestion.

We determined how LLC cells in vitro respond to a range of curcumin dosages applied for different durations. It was found that 24 to $30-\mathrm{hr}$ treatments reduced the number of cells in a dose-dependent
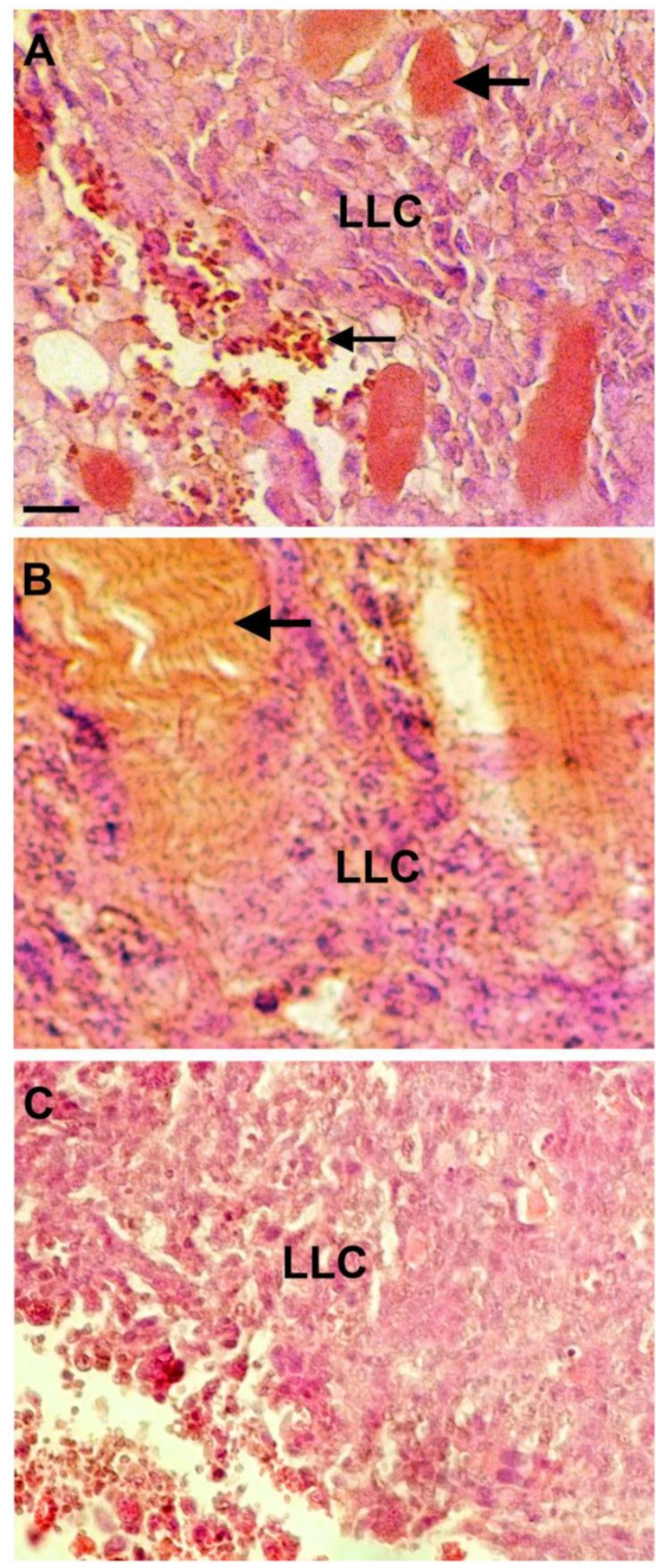

manner, which is in agreement with published results using other cell lines (1) as well as LLC (37). However, a shorter treatment interval ( 2 or $4 \mathrm{hrs}$ ) significantly reduced the density of cells only when they were treated with the highest curcumin dose $(60 \mu \mathrm{M})$. 
A

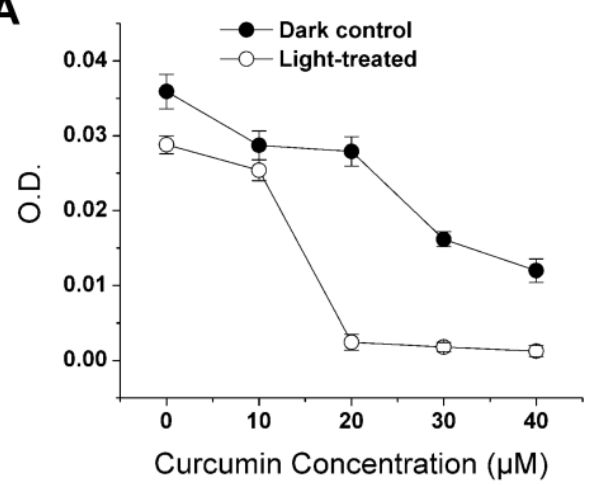

C

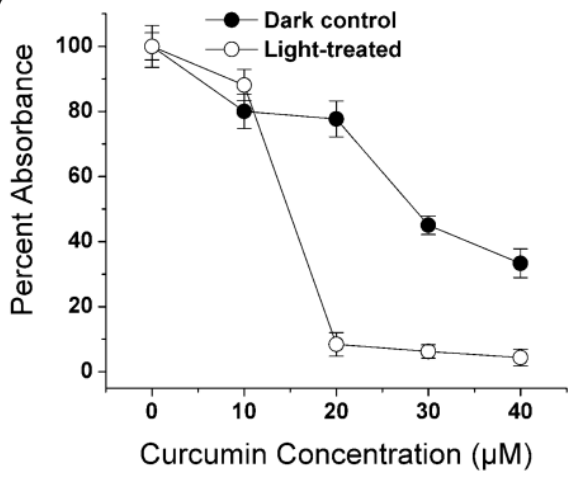

B

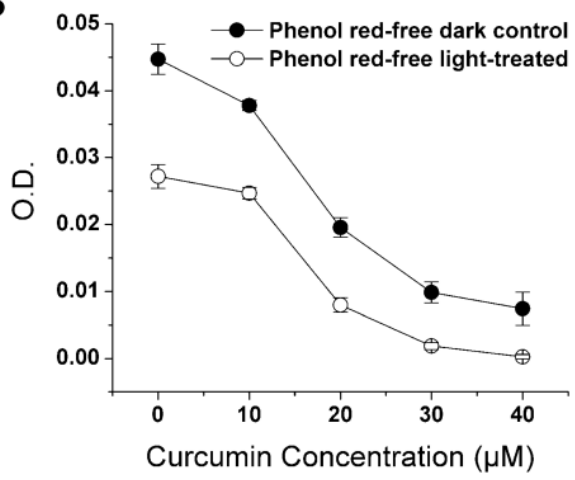

D

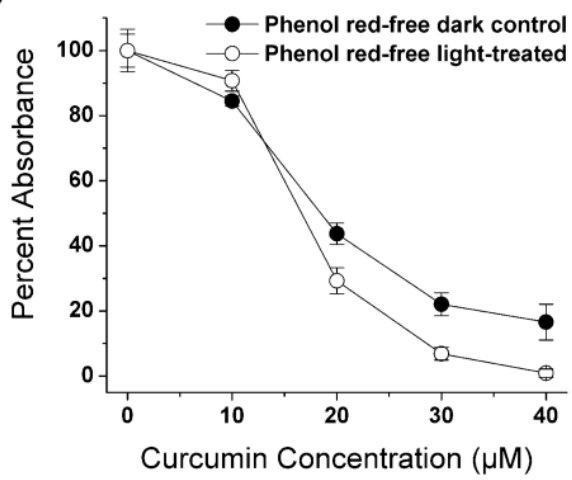

Figure 3. Effect of curcumin and visible light on LLC cell survival. LLC cells were pre-incubated with $0-40 \mu M$ curcumin for one hour and then either irradiated with visible light for 5 min or light protected (dark control). Curcumin was applied for a total of $30 \mathrm{hrs}$. A. Average absorbance following the crystal violet assay. B. Cells were treated as in A but were maintained in phenol red-free medium. C \& D. Same absorbance data as in A \& B replotted as percent of the zero-curcumin result. Each point is the mean of four wells \pm SD.

Because curcumin can alter a variety of molecular targets within cancer cells, we speculated that the cells that survived the treatment might be either a subset of the cell line that had greater intrinsic resistance to curcumin or LLC cells that had survived because they were modified by curcumin before it could exert its lethal effects. Curcumin affects cellular pathways that rely on AP-1, HIF-1, AKT, NF-kB, and other cell signals $(3,6,38-45)$. It has been argued that the elevated NFkB activity commonly found in more aggressive cancer cells endows them with anti-apoptotic properties but also makes them particularly vulnerable to negative selection by curcumin (5, 46-48). Any cell alteration that would explain curcumin effects in this study would need to be transmissible to daughter cells by either genetic or epigenetic changes.

A third possibility is that the surviving cells were not different from other cells and merely escaped curcumin by chance. To determine the characteristics of the surviving subpopulation, we compared the growth rate, tumorigenicity, and the NF-KB and ALDH1A1 expression levels of both lines. The surviving population showed a lower level in each of these categories, suggesting that there was either selection for a less aggressive line or generation of such a line by the curcumin treatment, what we are referring to as modification. Because the surviving cell line was found to be different from the original line, the third possibility, which does not infer special characteristics of the survivors, can be rejected.

Similarly, the curcumin exposure that was applied to the curcumin-surviving cell line revealed a slightly lower sensitivity to curcumin relative to the original line, indicating that the procedure may have selected for a more resistant subpopulation from within the original line or, instead, altered a small number of cells during the treatment thereby allowing 
them to survive. The $\mathrm{LD}_{50}$ for curcumin was increased by about $50 \%$. This result has implications for any cancer therapy in which cucumin is used as a chemotherapeutic agent against cancer cells, rather than merely as a dietary supplement intended to serve as a cancer preventative. Instead of the typical outcome observed with other chemotherapeutics, curcumin does not appear to leave behind more aggressive and curcumin-resistant tumor cells that could lead to cancer recurrence.

The outcome of the tumor growth experiment is consistent with the apparently slower growth of the curcumin-surviving cells in vitro relative to the original LLC cells. These cells remained tumorigenic but did so less effectively, perhaps because of their slower growth rate. Although LLC cells may be representative of other cancer cell types, these results should be confirmed by examining the curcumin-surviving progeny of cancer cells derived from distinctly different tissues.

The results of these experiments are consistent with recent reports that indicate a loss of CSCs from cancer cell lines in response to a single curcumin treatment (49-51). According to the CSC theory, tumor recurrence and metastasis are primarily caused by a small subpopulation of self-renewing cells that can differentiate into other cancer cells. CSCs are considered to be aggressive and more resistant cells that escape from chemotherapy. In contrast, the surviving LLC cells had slower replication, slightly greater resistance to curcumin, and lower levels of ALDH1A1 and NF- $\mathrm{kB}$, which are considered markers of CSCs (52-54) and found in more robust cancer cells $(55,56)$. Although we have no direct evidence of CSCs in the LLC cell line, the explanation above does agree with the results and should be explored further by searching for additional characteristics of CSCs in the cell cultures and LLC tumors.

Studies suggest that direct interactions between CSCs and curcumin are credible (25). For example, resistance to curcumin in melanoma cells has been attributed to high expression of the ATP-binding cassette transporter ABCA1 leading to efflux of curcumin from the cells (57). ABC transporters may provide CSCs with multidrug resistance that allows them to survive chemotherapy (58). Exclusion of fluorescent dyes by the elevated activity of $\mathrm{ABC}$ transporters can be used to identify putative CSCs and non-cancer stem cells $(24,59)$ and should be applied to LLC cells.

One study does, however, suggest that the LLC line lacks a distinct CSC subpopulation and argues instead that nearly all of the cells are tumorigenic (60). Nevertheless, the specific proportion of CSC cells found in cancer cell lines is apparently quite variable between lines and somewhat plastic within lines as it changes with factors in the media that have yet to be fully characterized (61). Results of the present study seem to be best explained by curcumin either producing a sustained suppression of the CSC subpopulation or tempering the aggressive tumorigenicity and growth that is perhaps characteristic of all cells within the LLC line. In either case, curcurmin may have caused an increased differentiation of the cells away from the normal LLC phenotype as has been described for its effects on stem cells (51).

We favor an explanation in which CSC properties are diminished by curcumin because this clarifies why the curcumin-surviving cell line appears less tumorigenic, and less sensitive to curcumin, and also expresses less of the markers of aggressive cells that are also attributes of CSCs. CSCs are hypothesized to divide slowly in tumors, thereby providing one explanation for how they escape the effects of anti-mitotic chemotherapy (62), but it is not clear whether they divide faster in vitro than non-CSCs. One interpretation of the slower growth of the curcumin-surviving line is that it contains fewer aggressively dividing cells which may or may not be CSCs. If curcumin is acting on CSCs within the LLC line, then this explanation requires that curcumin acts unlike the many other chemicals that are toxic to cancer cells, because CSCs are considered resistant to standard chemotherapies, whereas these cells appear to be selectively targeted by curcumin. This targeting would be either elimination or modification of the CSCs. Treatments employing curcumin or curcumin derivatives could be particularly effective supplements for conventional cancer treatments if they eliminate, differentiate, or weaken CSCs.

In support of this argument, a cell subpopulation with stem cell properties in the C6 rat glioma cell line is selectively eliminated by curcumin treatment (25), and curcumin encapsulated in nanoparticles may be effective at inhibiting stem cells implicated in brain tumor growth (50). Evidence also indicates that curcumin promotes brain neurogenesis from stem cells by inhibiting histone acetylation, further promoting its use against gliomas (27) and possibly lung cancer. Cancer stem cell characteristics are diminished in a breast cancer cell line given curcumin (26). Furthermore, colon cancer cells isolated according to the stem-cell marker aldehyde dehydrogenase are suppressed by a cucumin analog (63). Colon cancer stem cells appear to be effectively killed by treatments of curcumin combined with conventional chemotherapeutic agents such as 5-fluorouracil or cisplatin (28, 49). 
Although curcumin has cancer prevention potential and therapeutic value, its poor absorption and high rate of degradation could limit clinical applications $(51,64)$. Therefore, we conducted the light experiment to evaluate how to enhance the effectiveness of curcumin. The results showed that visible light and curcumin reduced the LLC cell population by about half at a concentration as low as $20 \mu \mathrm{M}$, which is consistent with previous findings (34), although those studies found significant effects at lower curcumin concentrations than we did. Because the reduction in LLC cells was smaller when phenol red was not present, we suggest that some of the phototoxicity was caused by light interacting with this dye rather than just with curcumin or from an additional effect of phenol red. Phenol red has been described as estrogenic in some cell lines (65). How this effect might produce greater phototoxicity in LLC cells is unclear.

Nevertheless, our results suggest that the phototoxicity from curcumin in other cancer cell lines may also be due in part to light interacting with phenol red. We also detected cell loss in response to light in phenol red-free medium without curcumin present, and this effect was smaller in the complete medium, suggesting that some of the effective wavelengths of light were absorbed by the complete medium. Because of this cell death caused by light alone, substantially more intense light treatments were not tested. The light intensity used here was roughly comparable to the intensity of sunlight on an overcast day.

The outcome of photodynamic therapy has been positive for some types of lung cancer (66). Our results suggest that curcumin delivered directly to tumors or through the circulation could be made more effective when combined with existing photodynamic equipment capable of producing suitable light in the visible spectrum. According to curcumin's peak absorption in the blue range this wavelength would be expected to be most effective. Curcumin is degraded in the intestinal lumen before absorption, in the liver, and elsewhere (67). A curcumin treatment used along with some form of light therapy might offset losses of curcumin in the body by making lower doses more biologically active.

\section{Acknowledgements}

The authors thank Dr. Stephen Kennel for providing LLC cells and Ms. Taghreed Al-Manaa for her technical assistance. This project was supported by the BGSU Departments of Public Health and Biological Sciences.

\section{Conflict of Interest}

The authors have declared that no conflict of interest exists.

\section{References}

1. Lopez-Lazaro M. Anticancer and carcinogenic properties of curcumin: considerations for its clinical development as a cancer chemopreventive and chemotherapeutic agent. Mol Nutr Food Res. 2008;52 Suppl 1:S103-27.

2. Yang CL, Ma YG, Xue YX, Liu YY, Xie H, Qiu GR. Curcumin Induces Small Cell Lung Cancer NCI-H446 Cell Apoptosis via the Reactive Oxygen Species-Mediated Mitochondrial Pathway and Not the Cell Death Receptor Pathway. DNA Cell Biol. 2011; doi: 10.1089/dna.2011.1300.

3. Ravindran J, Prasad S, Aggarwal BB. Curcumin and cancer cells: how many ways can curry kill tumor cells selectively? The AAPS journal. 2009;11(3):495-510.

4. Zanotto-Filho A, Braganhol E, Edelweiss MI, Behr GA, Zanin R, Schroder R, et al. The curry spice curcumin selectively inhibits cancer cells growth in vitro and in preclinical model of glioblastoma. The Journal of nutritional biochemistry. 2011; Epub.

5. Shishodia S, Amin HM, Lai R, Aggarwal BB. Curcumin (diferuloylmethane) inhibits constitutive NF-kappaB activation, induces G1/S arrest, suppresses proliferation, and induces apoptosis in mantle cell lymphoma. Biochem Pharmacol. 2005;70(5):700-13.

6. Wilken R, Veena MS, Wang MB, Srivatsan ES. Curcumin: A review of anti-cancer properties and therapeutic activity in head and neck squamous cell carcinoma. Molecular cancer. 2011;10:12.

7. Teiten MH, Gaascht F, Eifes S, Dicato M, Diederich M. Chemopreventive potential of curcumin in prostate cancer. Genes \& nutrition. 2010;5(1):61-74.

8. Maheshwari RK, Singh AK, Gaddipati J, Srimal RC. Multiple biological activities of curcumin: a short review. Life Sci. 2006;78(18):2081-7.

9. Huang MT, Newmark HL, Frenkel K. Inhibitory effects of curcumin on tumorigenesis in mice. Journal of cellular biochemistry Supplement. 1997;27:26-34.

10. Hecht SS, Kenney PM, Wang M, Trushin N, Agarwal S, Rao $\mathrm{AV}$, et al. Evaluation of butylated hydroxyanisole, myo-inositol, curcumin, esculetin, resveratrol and lycopene as inhibitors of benzo[a]pyrene plus 4-(methylnitrosamino)-1-(3-pyridyl)-1-butanone-induced lung tumorigenesis in A/J mice. Cancer Lett. 1999;137(2):123-30.

11. Aravindan N, Madhusoodhanan R, Ahmad S, Johnson D, Herman TS. Curcumin inhibits NFkappaB mediated radioprotection and modulate apoptosis related genes in human neuroblastoma cells. Cancer Biol Ther. 2008;7(4):569-76.

12. Kunnumakkara AB, Diagaradjane P, Guha S, Deorukhkar A, Shentu S, Aggarwal BB, et al. Curcumin sensitizes human colorectal cancer xenografts in nude mice to gamma-radiation by targeting nuclear factor-kappaB-regulated gene products. Clin Cancer Res. 2008;14(7):2128-36.

13. Chendil D, Ranga RS, Meigooni D, Sathishkumar S, Ahmed MM. Curcumin confers radiosensitizing effect in prostate cancer cell line PC-3. Oncogene. 2004;23(8):1599-607.

14. Javvadi P, Segan AT, Tuttle SW, Koumenis C. The chemopreventive agent curcumin is a potent radiosensitizer of human cervical tumor cells via increased reactive oxygen species production and overactivation of the mitogen-activated protein kinase pathway. Mol Pharmacol. 2008;73(5):1491-501. 
15. Kim BY, Kim KA, Kwon O, Kim SO, Kim MS, Kim BS, et al. NF-kappaB inhibition radiosensitizes Ki-Ras-transformed cells to ionizing radiation. Carcinogenesis. 2005;26(8):1395-403.

16. Veeraraghavan J, Natarajan M, Herman TS, Aravindan N. Curcumin-altered p53-response genes regulate radiosensitivity in p53-mutant Ewing's sarcoma cells. Anticancer Res. 2010;30(10):4007-15.

17. Kamat AM, Tharakan ST, Sung B, Aggarwal BB. Curcumin potentiates the antitumor effects of Bacillus Calmette-Guerin against bladder cancer through the downregulation of NF-kappaB and upregulation of TRAIL receptors. Cancer Res. 2009;69(23):8958-66.

18. Kunnumakkara AB, Guha $S$, Krishnan $S$, Diagaradjane $P$, Gelovani J, Aggarwal BB. Curcumin potentiates antitumor activity of gemcitabine in an orthotopic model of pancreatic cancer through suppression of proliferation, angiogenesis, and inhibition of nuclear factor-kappaB-regulated gene products. Cancer Res. 2007;67(8):3853-61.

19. Notarbartolo M, Poma P, Perri D, Dusonchet L, Cervello M, D'Alessandro N. Antitumor effects of curcumin, alone or in combination with cisplatin or doxorubicin, on human hepatic cancer cells. Analysis of their possible relationship to changes in NF-kB activation levels and in IAP gene expression. Cancer Lett. 2005;224(1):53-65.

20. Dhandapani KM, Mahesh VB, Brann DW. Curcumin suppresses growth and chemoresistance of human glioblastoma cells via AP-1 and NFkappaB transcription factors. J Neurochem. 2007;102(2):522-38.

21. Jagetia GC. Radioprotection and radiosensitization by curcumin. Adv Exp Med Biol. 2007;595:301-20.

22. Goel A, Aggarwal BB. Curcumin, the golden spice from Indian saffron, is a chemosensitizer and radiosensitizer for tumors and chemoprotector and radioprotector for normal organs. Nutrition and cancer. 2010;62(7):919-30.

23. Eyler CE, Rich JN. Survival of the fittest: cancer stem cells in therapeutic resistance and angiogenesis. Journal of clinical oncology : official journal of the American Society of Clinical Oncology. 2008;26(17):2839-45.

24. D'Angelo RC, Wicha MS. Stem cells in normal development and cancer. Prog Mol Biol Transl Sci. 2010;95:113-58.

25. Fong D, Yeh A, Naftalovich R, Choi TH, Chan MM. Curcumin inhibits the side population (SP) phenotype of the rat $\mathrm{C} 6$ glioma cell line: towards targeting of cancer stem cells with phytochemicals. Cancer Lett. 2010;293(1):65-72.

26. Kakarala M, Brenner DE, Korkaya H, Cheng C, Tazi K, Ginestier C, et al. Targeting breast stem cells with the cancer preventive compounds curcumin and piperine. Breast Cancer Res Treat. 2010; 122(3):777-85.

27. Kang SK, Cha SH, Jeon HG. Curcumin-induced histone hypoacetylation enhances caspase-3-dependent glioma cell death and neurogenesis of neural progenitor cells. Stem Cells Dev. 2006;15(2):165-74.

28. Nautiyal J, Kanwar SS, Yu Y, Majumdar AP. Combination of dasatinib and curcumin eliminates chemo-resistant colon cancer cells. Journal of molecular signaling. 2011;6(1):7.

29. Geusz ME, Blakely KT, Hiler DJ, Jamasbi RJ. Elevated mPer1 gene expression in tumor stroma imaged through bioluminescence. Int J Cancer. 2010;126(3):620-30.

30. Lundkvist GB, Kwak Y, Davis EK, Tei H, Block GD. A calcium flux is required for circadian rhythm generation in mammalian pacemaker neurons. J Neurosci. 2005;25(33):7682-6.

31. Shen HM, Tergaonkar V. NFkappaB signaling in carcinogenesis and as a potential molecular target for cancer therapy. Apoptosis. 2009;14(4):348-63.

32. Mehlen P, Kretz-Remy C, Preville X, Arrigo AP. Human hsp27, Drosophila hsp27 and human alphaB-crystallin expression-mediated increase in glutathione is essential for the protective activity of these proteins against TNFalpha-induced cell death. Embo J. 1996;15(11):2695-706.

33. Tonnesen $\mathrm{HH}$, de Vries $\mathrm{H}$, Karlsen J, Beijersbergen van Henegouwen G. Studies on curcumin and curcuminoids. IX: Investigation of the photobiological activity of curcumin using bacterial indicator systems. Journal of pharmaceutical sciences. 1987;76(5):371-3.

34. Dujic J, Kippenberger S, Hoffmann S, Ramirez-Bosca A, Miquel J, Diaz-Alperi J, et al. Low concentrations of curcumin induce growth arrest and apoptosis in skin keratinocytes only in combination with UVA or visible light. J Invest Dermatol. 2007;127(8):1992-2000.

35. Dujic J, Kippenberger S, Ramirez-Bosca A, Diaz-Alperi J, Bereiter-Hahn J, Kaufmann R, et al. Curcumin in combination with visible light inhibits tumor growth in a xenograft tumor model. Int J Cancer. 2009;124(6):1422-8.

36. Choudhuri T, Pal S, Agwarwal ML, Das T, Sa G. Curcumin induces apoptosis in human breast cancer cells through p53-dependent Bax induction. FEBS Lett. 2002;512(1-3):334-40.

37. Ichiki K, Mitani N, Doki Y, Hara H, Misaki T, Saiki I. Regulation of activator protein-1 activity in the mediastinal lymph node metastasis of lung cancer. Clin Exp Metastasis. 2000;18(7):539-45.

38. Aggarwal S, Ichikawa H, Takada Y, Sandur SK, Shishodia S, Aggarwal BB. Curcumin (diferuloylmethane) down-regulates expression of cell proliferation and antiapoptotic and metastatic gene products through suppression of IkappaBalpha kinase and Akt activation. Mol Pharmacol. 2006;69(1):195-206.

39. Liu Q, Loo WT, Sze SC, Tong Y. Curcumin inhibits cell proliferation of MDA-MB-231 and BT-483 breast cancer cells mediated by down-regulation of NFkappaB, cyclinD and MMP-1 transcription. Phytomedicine : international journal of phytotherapy and phytopharmacology. 2009;16(10):916-22.

40. Chiu TL, Su CC. Curcumin inhibits proliferation and migration by increasing the Bax to Bcl-2 ratio and decreasing NF-kappaBp65 expression in breast cancer MDA-MB-231 cells. International journal of molecular medicine. 2009;23(4):469-75.

41. Su CC, Lin JG, Li TM, Chung JG, Yang JS, Ip SW, et al. Curcumin-induced apoptosis of human colon cancer colo 205 cells through the production of ROS, Ca2+ and the activation of caspase-3. Anticancer Res. 2006;26(6B):4379-89.

42. Zheng M, Ekmekcioglu S, Walch ET, Tang $\mathrm{CH}$, Grimm EA. Inhibition of nuclear factor-kappaB and nitric oxide by curcumin induces $\mathrm{G} 2 / \mathrm{M}$ cell cycle arrest and apoptosis in human melanoma cells. Melanoma research. 2004;14(3):165-71.

43. Wahl H, Tan L, Griffith K, Choi M, Liu JR. Curcumin enhances Apo2L/TRAIL-induced apoptosis in chemoresistant ovarian cancer cells. Gynecologic oncology. 2007;105(1):104-12.

44. Singh M, Singh N. Molecular mechanism of curcumin induced cytotoxicity in human cervical carcinoma cells. Mol Cell Biochem. 2009;325(1-2):107-19.

45. Mehta K, Pantazis P, McQueen T, Aggarwal BB. Antiproliferative effect of curcumin (diferuloylmethane) against human breast tumor cell lines. Anticancer Drugs. 1997;8(5):470-81.

46. Freudlsperger C, Greten J, Schumacher U. Curcumin induces apoptosis in human neuroblastoma cells via inhibition of NFkappaB. Anticancer Res. 2008;28(1A):209-14.

47. Kim K, Ryu K, Ko Y, Park C. Effects of nuclear factor-kappaB inhibitors and its implication on natural killer T-cell lymphoma cells. Br J Haematol. 2005;131(1):59-66.

48. Sandur SK, Deorukhkar A, Pandey MK, Pabon AM, Shentu S, Guha $S$, et al. Curcumin modulates the radiosensitivity of colorectal cancer cells by suppressing constitutive and inducible NF-kappaB activity. International journal of radiation oncology, biology, physics. 2009;75(2):534-42. 
49. Yu Y, Kanwar SS, Patel BB, Nautiyal J, Sarkar FH, Majumdar AP. Elimination of Colon Cancer Stem-Like Cells by the Combination of Curcumin and FOLFOX. Transl Oncol. 2009;2(4):321-8.

50. Lim KJ, Bisht S, Bar EE, Maitra A, Eberhart CG. A polymeric nanoparticle formulation of curcumin inhibits growth, clonogenicity and stem-like fraction in malignant brain tumors. Cancer Biol Ther. 2011;11(5):464-73.

51. Zhang XZ, Li XJ, Zhang HY. Curcumin's potential to modulate stem cell fate. Trends in pharmacological sciences. 2009;30(7):331-2.

52. Alison MR, Lim SM, Nicholson LJ. Cancer stem cells: problems for therapy? J Pathol. 2011;223(2):147-61.

53. Alison MR, Guppy NJ, Lim SM, Nicholson LJ. Finding cancer stem cells: are aldehyde dehydrogenases fit for purpose? J Pathol. 2010;222(4):335-44.

54. Douville J, Beaulieu R, Balicki D. ALDH1 as a functional marker of cancer stem and progenitor cells. Stem Cells Dev. 2009;18(1):17-25.

55. Shen HM, Tergaonkar V. NFkappaB signaling in carcinogenesis and as a potential molecular target for cancer therapy. Apoptosis. 2009 Apr;14(4):348-63.

56. Cortes Sempere M, Rodriguez Fanjul V, Sanchez Perez I, Perona R. The role of the NFkappaB signalling pathway in cancer. Clinical \& translational oncology : official publication of the Federation of Spanish Oncology Societies and of the National Cancer Institute of Mexico. 2008;10(3):143-7.

57. Bachmeier BE, Iancu CM, Killian PH, Kronski E, Mirisola V, Angelini G, et al. Overexpression of the ATP binding cassette gene ABCA1 determines resistance to Curcumin in M14 melanoma cells. Molecular cancer. 2009;8:129.

58. Zhou BB, Zhang H, Damelin M, Geles KG, Grindley JC, Dirks PB. Tumour-initiating cells: challenges and opportunities for anticancer drug discovery. Nature reviews Drug discovery. 2009;8(10):806-23.

59. Pearce DJ, Bonnet D. The combined use of Hoechst efflux ability and aldehyde dehydrogenase activity to identify murine and human hematopoietic stem cells. Exp Hematol. 2007;35(9):1437-46.

60. Yoo MH, Hatfield DL. The cancer stem cell theory: is it correct? Molecules and cells. 2008;26(5):514-6.

61. Rosen JM, Jordan CT. The increasing complexity of the cancer stem cell paradigm. Science. 2009;324(5935):1670-3.

62. Clevers $H$. The cancer stem cell: premises, promises and challenges. Nat Med. 2011;17(3):313-9.

63. Lin L, Liu Y, Li H, Li PK, Fuchs J, Shibata H, et al. Targeting colon cancer stem cells using a new curcumin analogue, GO-Y030. Br J Cancer. 2011;105(2):212-20.

64. Anand P, Kunnumakkara AB, Newman RA, Aggarwal BB. Bioavailability of curcumin: problems and promises. Mol Pharm. 2007;4(6):807-18.

65. Wesierska-Gadek J, Schreiner T, Maurer M, Waringer A, Ranftler C. Phenol red in the culture medium strongly affects the susceptibility of human MCF-7 cells to roscovitine. Cellular \& molecular biology letters. 2007;12(2):280-93.

66. Maziak DE, Markman BR, MacKay JA, Evans WK. Photodynamic therapy in nonsmall cell lung cancer: a systematic review. The Annals of thoracic surgery. 2004;77(4):1484-91.

67. Pan MH, Huang TM, Lin JK. Biotransformation of curcumin through reduction and glucuronidation in mice. Drug Metab Dispos. 1999;27(4):486-94. 